\title{
Species richness of squamate reptiles from two islands in the Mexican Pacific
}

\author{
Uriel Hernández-Salinas ${ }^{1}$, Aurelio Ramírez-Bautista ${ }^{2 *}$, and Vicente Mata-Silva ${ }^{3}$ \\ 1 Instituto Politécnico Nacional, CIIDIR Unidad Durango, Sigma 119, Fraccionamiento 20 de Noviembre II, Durango, Durango, 34220 , México. \\ 2 Centro de Investigaciones Biológicas, Universidad Autónoma del Estado de Hidalgo, A.P. 1-69 Plaza Juárez, C. P. 42001, Pachuca, Hidalgo, México. \\ 3 Department of Biological Sciences, The University of Texas at El Paso, Texas 79968, U.S.A. \\ * Corresponding autor. E-mail: ramibautistaa@gmail.com
}

\begin{abstract}
Cocinas and San Pancho Islands, located in the Bay of Chamela, Jalisco, México, are two of the few remaining island ecosystems with little ecological disturbance. We studied both islands aiming to assess their reptile richness. Because the environment in Chamela is seasonal, we conducted biodiversity surveys during six samplings: three in the dry season and three in rainy season. We found a total of seven reptile species on Cocinas and San Pancho Islands representing the first description of their herpetofauna. We recorded four species (Aspidoscelis lineattissima, Hemidactylus frenatus, Iguana iguana, and Urosaurus bicarinatus) on Cocinas Island, and six species (A. lineattissima, Phyllodactylus lanei, H. frenatus, Anolis nebulosus, Urosaurus bicarinatus, and Boa constrictor) on San Pancho Island. Species richness in Cocinas showed a higher evenness than in San Pancho Island. Finally, A. lineattissima and A. nebulosus were the dominant species on Cocinas and San Pancho Islands, respectively.
\end{abstract}

DOI: $10.15560 / 10.6 .1264$

\section{INTRODUCTION}

Species richness is defined as the number of species in a community or a geographical area (Whittaker 1972; Magurran 2004). This measure has been used as an indicator of biodiversity in islands and mainland environments (Hortal et al. 2009); additionally, more statistical tools have been developed for a better estimation and understanding of the comparisons among communities (Gotelli and Chao 2013). Reptiles, amphibians, mammals, and birds are the main vertebrates that have been studied for comparing species richness between islands and mainland environments (Magurran 2004); however, regions that lack species inventories still exist, and many of those that have been performed remain incomplete (Whittaker and Fernández-Palacios 2010).

Species richness in reptiles from Mexico has been the most extensively studied subject in almost all environments (Flores-Villela and García-Vázquez 2014). The high reptile diversity of Mexico has led to it being considered one of the most important biological regions of the world (Wilson et al. 2013). Mexico's current species richness (1227 species; Wilson et al. 2013) and its endemics (57\%; Wilson et al. 2013; Flores-Villela and García-Vázquez 2014) are a reflection of the topographic and physiographic complexity of its landscapes (Wilson et al. 2013).

Currently, there are few studies that have addressed species richness of reptiles from some islands off of the Pacific Coast of Mexico (Ramirez-Bautista 1994). Furthermore, although those studies provided important data regarding species number, statistical analysis of species richness was not addressed. For instance, Stejneger (1899) reported 13 reptile species from Isabel Island; later, Uribe-Peña and Gaviño de la Torre (1978) recorded only two lizards and one snake for the same island. Other studies from Tres Marías Islands carried out by Zweifel (1960), recorded three turtles, one crocodile, five lizards, and twelve snakes, and Casas-Andreu (1992) recorded nine species of lizards. Thus far, the best studied islands in terms of their herpetofauna are located on the Pacific Ocean of northern Mexico, mainly from the Gulf of California and Southern Baja California (Grismer 2002; Murphy and Mendez de la Cruz 2010). However, currently we have very little information in regards to species richness of some islands from Chamela Bay (Anegados, Pajarera, Novillas, Cocinas, Mamut, Colorada, La Mosca, San Agustín, San Pancho, San Andrés and La Negrita, Figure 1) in the Pacific Coast of Jalisco, Mexico. The National Commission of Natural Protected Areas from the Mexican government (CONANP 2008) proposed Chamela Bay as a Protected Natural Area; however, at the present there is little information about the vertebrate communities of this region, particularly on San Pancho and Cocinas Islands. Therefore, we perceive the information provided herein (species richness) as the first in depth assessment of reptiles inhabiting these two Islands.

\section{MATERIALS AND METHODS}

Study site

Cocinas and San Pancho islands are located in Chamela Bay, in La Huerta, Jalisco, Mexico (Figure 1). Cocinas Island is located in the middle of the bay $\left(19^{\circ} 32^{\prime} 49^{\prime \prime} \mathrm{N}, 105^{\circ}\right.$ $06^{\prime} 35^{\prime \prime} \mathrm{W}$; datum: WGS84), being one of the largest islands of the bay. It encompasses $c a .32$ ha, with a maximum elevation of $55 \mathrm{~m}$; this island is situated $c a .2 .17 \mathrm{~km}$ from mainland (CONANP 2008). Vegetation in Cocinas Island is represented primarily by tropical deciduous forest and xerophytic scrub (CONANP 2008). On the other hand, 


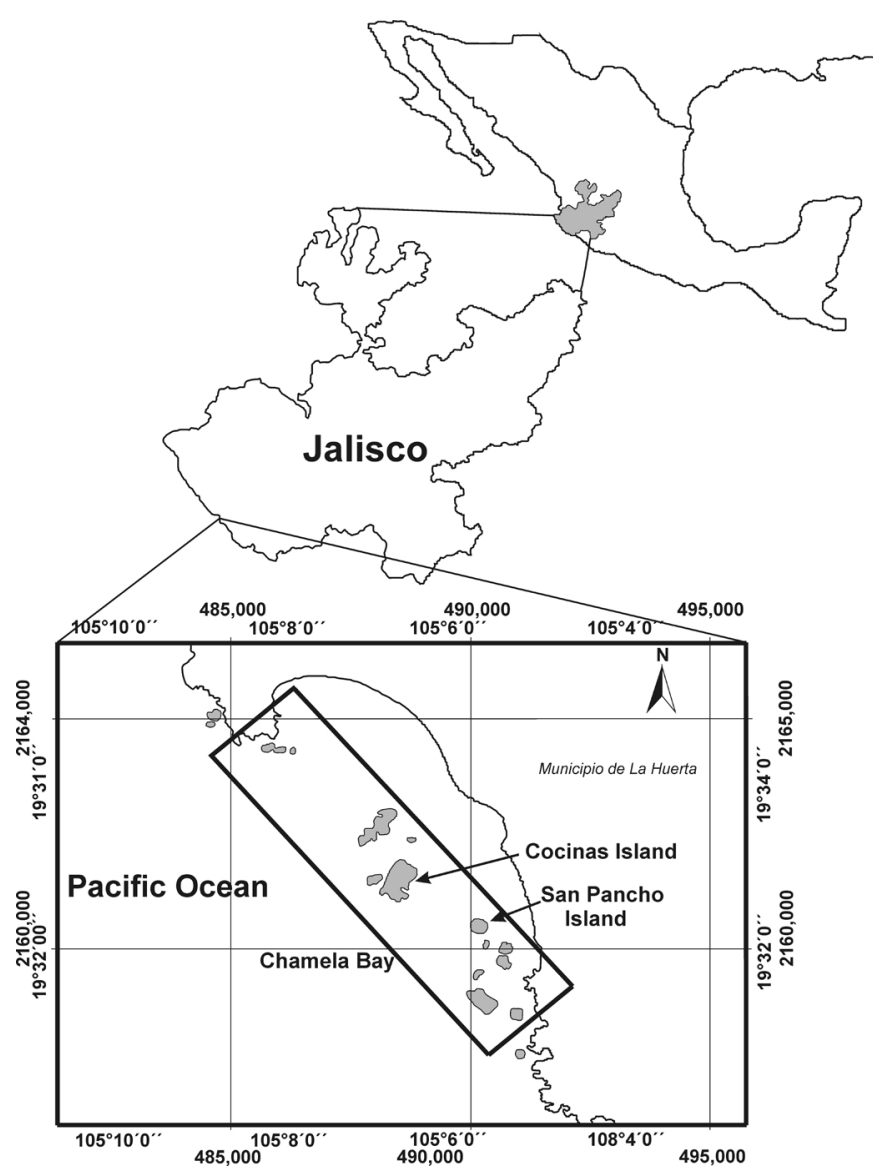

FIgURE 1. Geographic location of Chamela Bay, showing Cocinas and San Pancho islands in Jalisco, México. CONANP's map (2008) modified by the first author.

San Pancho Island is located on the southern portion of Chamela Bay $\left(19^{\circ} 33^{\prime} 15^{\prime \prime} \mathrm{N}, 105^{\circ} 07^{\prime} 44^{\prime \prime} \mathrm{W}\right.$; datum: WGS84; Figure 1), comprising an area of $c a .2 .2$ ha, with a maximum elevation of $37 \mathrm{~m}$. The maximum length of this island is slightly over $430 \mathrm{~m}$ and its width is slightly greater than $50 \mathrm{~m}$; it is located $c a .500 \mathrm{~m}$ from mainland (CONANP 2008). Like Cocinas Island, the dominant vegetation in San Pancho Island is represented by tropical deciduous forest and xerophytic scrub (CONANP 2008), as well.

\section{Sampling design}

Because the environment in the study area undergoes seasonal changes, visits to the area took place during the dry (December 2011, and March and October 2012) and rainy (June, August and October 2012) seasons. We conducted fieldwork for 15 days on Cocinas Island (6-8 December 2011, 18-20 March, 8-10 June, 29-31 August, and 17-19 October 2012), and for 15 days on San Pancho Island (18-20 December 2011, 24-26 March, 22-24 June, and 2-4 August and 21-23 October 2012). Searches were conducted by walking in straight-line transects across each island, recording any observed species (on ground and/or vegetation), their habitats and microhabitats, and behavior during daylight from 0900 to $1300 \mathrm{~h}$, and at night from 1900 to $2200 \mathrm{~h}$. We also examined potential microhabitats such as logs and other ground debris, and raked through leaf litter to uncover hidden reptiles if present (Moreno 2001). When individuals of unknown species were found, we proceeded to collect no more than two specimens per species for vouchers on both islands, in accordance to the laws of the Secretaría de Gestión para La
Proteción Ambiental, Dirección General de Vida Silvestre. Collected specimens were euthanized by freezing methods, then fixed in $10 \%$ formalin solution, and permanently preserved in $70 \%$ ethanol (Casas-Andreu et al. 1991). We deposited all voucher specimens in the Herpetology Collection of the Centro de Investigaciones Biológicas, Universidad Autónoma del Estado de Hidalgo, México.

\section{Data analysis}

We constructed species accumulation curves in order to assess completeness of the species inventory for each island (local species richness) using nonparametric estimators ACE and Chao1, which are based on abundance estimates (Magurran 1988; Moreno 2001; Hortal et al. 2006). The use of these two estimators allows a more accurate assessment regarding completeness of the inventories, and it is also assumed that both estimators similarly evaluate the species richness from each locality when their values are not substantially different (Moreno 2001). In order to compare the species richness between the two islands a rarefaction curve was constructed. The latter was based on species richness and number of individuals recorded for each species, on the assumption that the areas being compared are of different size (Gotelli and Colwell 2001). These curves were performed by using the Species Richness and Diversity Program IV 4.1.2. On the other hand, abundance of reptiles for each island was assessed with Whittaker or rank-abundance curves (Moreno 2001; Feinsinger 2003); therefore, we used species number and number of individuals per species from both islands. Curves were plotted according to the logarithm of the ratio for each species: $p(n / N)$; and the data were sorted in relation to the most abundant and least abundant species (Moreno 2001).

Sampling effort applied to calculate species richness and diversity on both islands was standardized to survey hours, which was always performed by three persons per number of hours based on the methodology proposed by Moreno (2001), (e.g., 4 hours per 3 persons = 12 survey hours).

\section{RESULTS}

\section{Species richness}

In order to estimate species richness for each island, we obtained a searching effort of 93 hours per area. Overall, we collected seven species on both islands, and from those species six were found on San Pancho Island and only four on Cocinas Island (Table 1; Figures 2 and 3). San Pancho Island had more reptiles by both family and species richness than Cocinas Island (Table 1). Lizards that we recorded on San Pancho Island included representatives of the families Phyllodactylidae, Gekkonidae, Phrynosomatidae, Teiidae and Dactyloidae; we also observed a snake of the family Boidae (Table 1). Species reported on Cocinas Island belonged to the families Gekkonidae, Iguanidae, Phrynosomatidae, and Teiidae (Table 1).

Species accumulation curves showed an asymptote for San Pancho Island (Figure 4A), but not for Cocinas Island. This suggests that additional species remain to be found on Cocinas Island (Figure 4B). The nonparametric estimator (ACE) showed a completeness of $100 \%$ for San Pancho Island and only $77 \%$ for Cocinas Island (Figure 
$4 \mathrm{~A}$ and B). Additionally, the inventory completeness estimated by Chao1 showed $85 \%$ for both San Pancho and Cocinas Islands (Figure 4A and B); showing for both cases an acceptable estimate according to the sampling effort for this group. Species richness was compared with rarefaction curves, which were based on samples with $95 \%$ confidence intervals, showing marked differences with respect to species number and individuals of each species between the islands (Figure 5). Differences of rarefaction curves lie on the number of species and the average density of each species per island, resulting in San Pancho Island having a rarefaction curve more pronounced or larger than that of Cocinas Island (Figure 5). Rank abundance curve for San Pancho Island showed higher evenness than in Cocinas Island (Figure 6). On Cocinas Island Aspidoscelis lineattissima Cope, 1878 was the most dominant species,
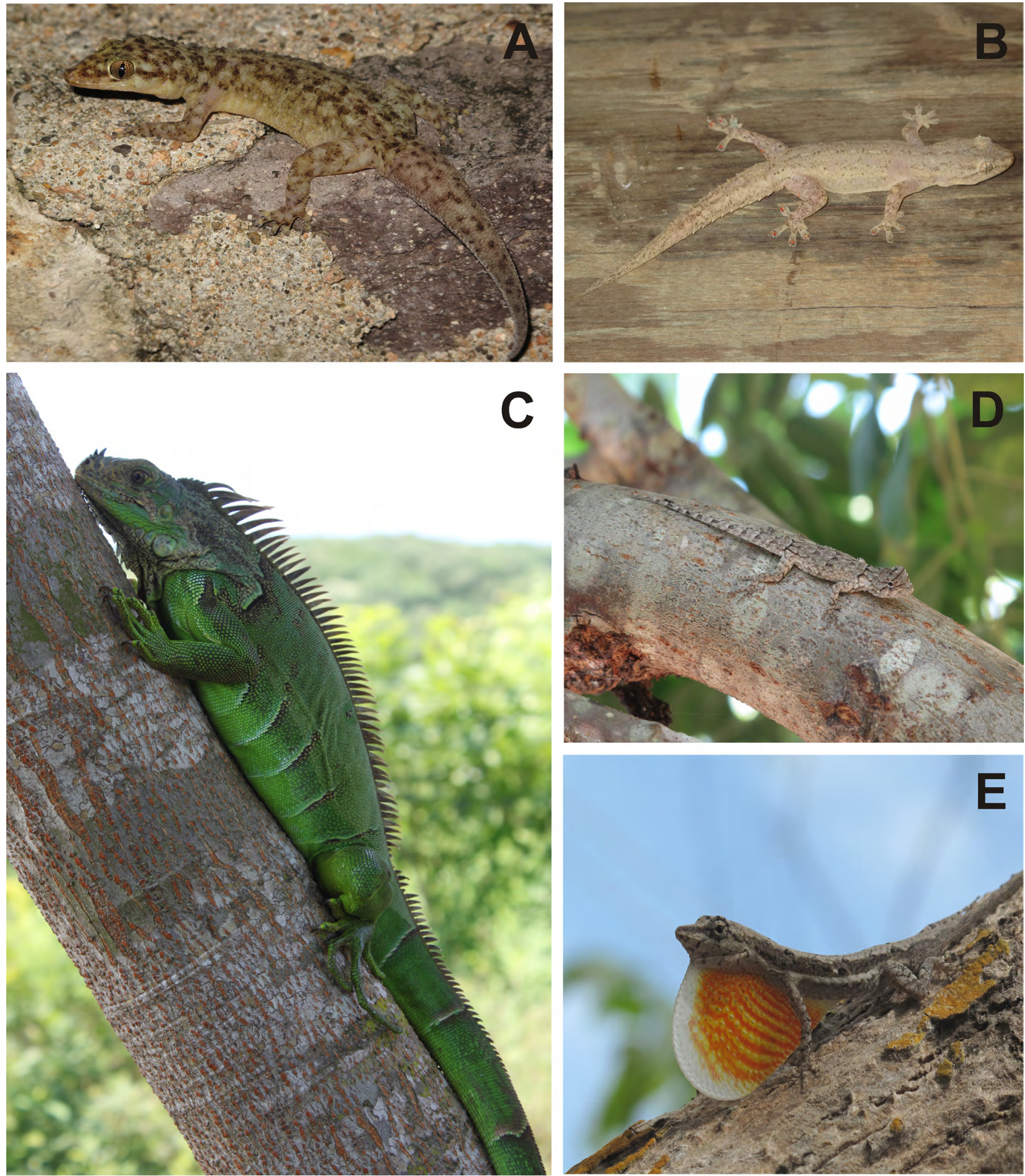

FigURE 2. Reptile species inhabiting San Pancho and Cocinas islands from Chamela Bay, Jalisco, Mexico. (A) Phyllodactylus lanei, (B) Hemidactylus frenatus, (C) Iguana iguana, (D) Urosaurus bicarinatus, and (E) Anolis nebulosus. Photo Credits: (A) Uriel Hernández-Salinas; (B) Christian BerriozabalIslas; (C) Daniel Lara-Tufiño; (D) Christian Berriozabal-Islas; (E) Uriel Hernández-Salinas. 

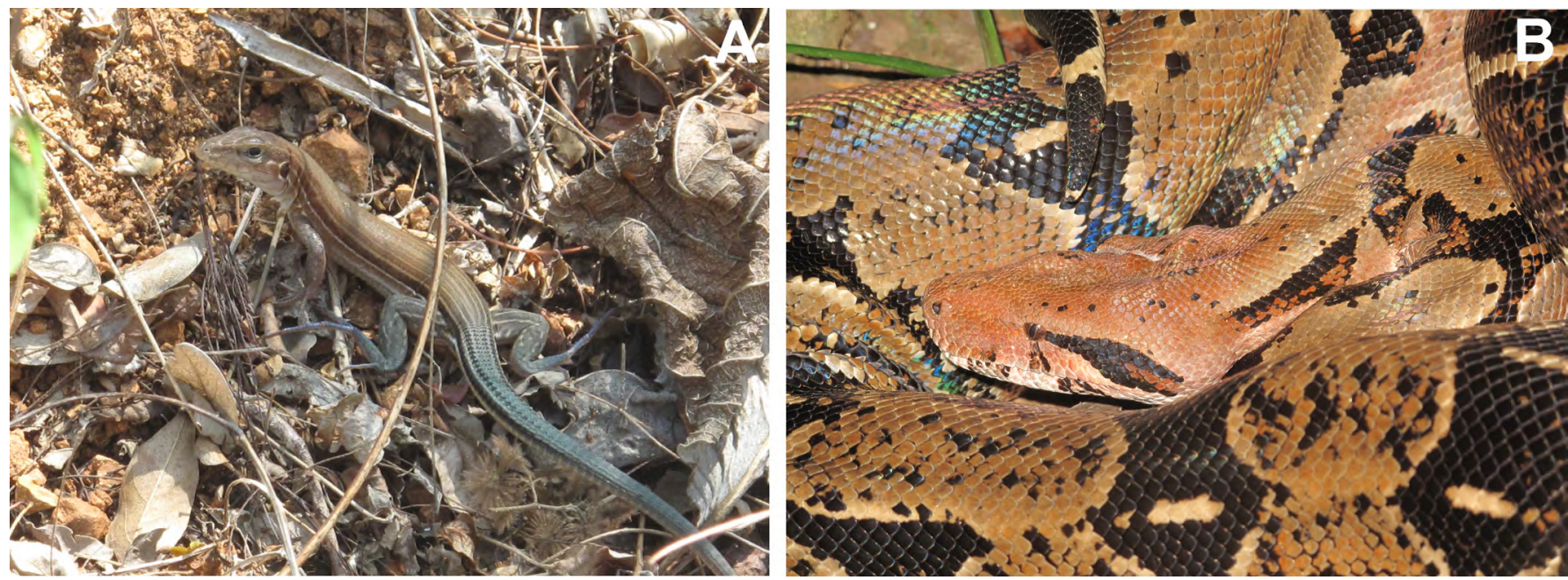

Figure 3. Reptile species inhabiting San Pancho and Cocinas islands from Chamela Bay, Jalisco, Mexico. (A) Aspidoscelis lineattissima and (B) Boa constrictor. Picture Credits: (A) Uriel Hernández-Salinas; (B) Christian Berriozabal-Islas.

TABLE 1. Species list from San Pancho and Cocinas islands, Chamela Bay, Jalisco, Mexico. ${ }^{*}=$ Species endemic to Mexico.

\begin{tabular}{lcc}
\hline $\begin{array}{l}\text { CLASS REPTILIA } \\
\text { ORDER SQUAMATA }\end{array}$ & $\begin{array}{c}\text { SAN PANCHO } \\
\text { ISLAND }\end{array}$ & $\begin{array}{c}\text { COCINAS } \\
\text { ISLAND }\end{array}$ \\
\hline $\begin{array}{l}\text { Family Phyllodactylidae } \\
\text { Phyllodactylus lanei* }\end{array}$ & $\mathrm{X}$ & \\
\hline $\begin{array}{l}\text { Family Gekkonidae } \\
\text { Hemidactylus frenatus }\end{array}$ & $\mathrm{X}$ & $\mathrm{X}$ \\
$\begin{array}{l}\text { Family Iguanidae } \\
\text { Iguana iguana }\end{array}$ & & $\mathrm{X}$ \\
\hline $\begin{array}{l}\text { Family Phrynosomatidae } \\
\text { Urosaurus bicarinatus* }\end{array}$ & $\mathrm{X}$ & $\mathrm{X}$ \\
\hline $\begin{array}{l}\text { Family Dactyloidae } \\
\text { Anolis nebulosus* }\end{array}$ & $\mathrm{X}$ & \\
\hline $\begin{array}{l}\text { Family Teiidae } \\
\text { Aspidoscelis lineattissima* }\end{array}$ & $\mathrm{X}$ & $\mathrm{X}$ \\
Family Boidae & $\mathrm{X}$ & \\
\hline Boa constrictor & & \\
\hline
\end{tabular}

while Hemidactylus frenatus Schlegel, 1836, Urosaurus bicarinatus (Duméril, 1856) and Iguana iguana (Linnaeus, 1758) were considered as rare (Figure 6). With respect to San Pancho Island, the most dominant species was Anolis nebulosus (Wiegmann, 1832), and the rarest species were U. bicarinatus, Phyllodactylus lanei Smith, 1935, and the snake Boa constrictor Linnaeus, 1758 (Figure 6).

\section{Discussion}

\section{Species richness}

Overall, the number of species recorded on both islands was lower than those reported for other continental islands with larger surface area along the Mexican Pacific Coast; for instance, Marías Islands (Zweifel 1960), Isabel Island (Uribe Peña and Gaviño de la Torre 1978), islands from Baja California (Grismer 1993), and the Gulf of California (Murphy and Crabtree 1985). Nevertheless, our study showed that species richness was higher in San Pancho Island than in Cocinas Island. These results could not be explained under the hypothesis of habitat diversity (Hortal et al. 2009), since it indicates that larger islands tend to have greater environmental heterogeneity than smaller islands. However, our calculations with species richness estimators predicted that in this case the larger island

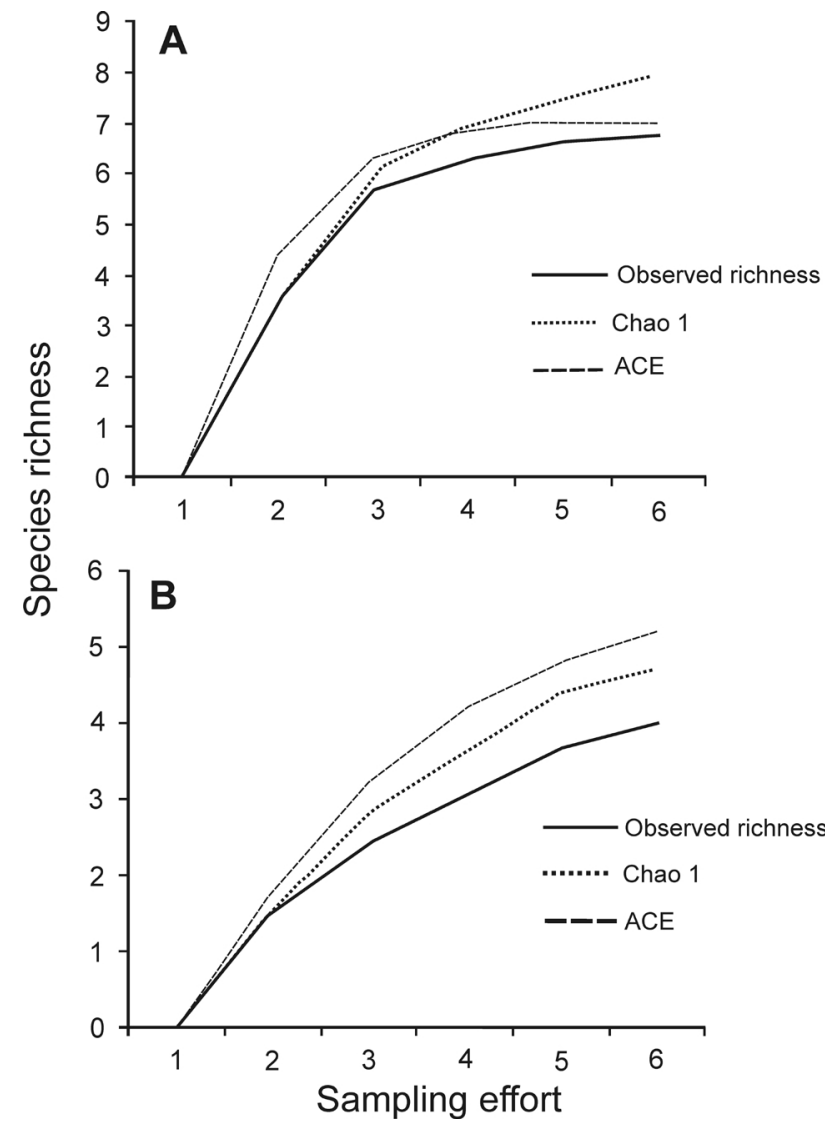

FIGURE 4. Species accumulation curves for reptiles on San Pancho Island (A) and Cocinas Island (B) of Chamela Bay, Jalisco, Mexico.

(Cocinas) should hold at least two additional species, and this result could possibly be substantiated with further sampling and consequently might lend support to the habitat diversity hypothesis. Lower number of species observed in Cocinas Island also could be explained by the location of this island in reference to mainland, as Cocinas Island is further away $(2.170 \mathrm{~km})$ than San Pancho Island. Additionally, these results could also be an indication of poor quality environments in relation to resource availability (low environmental heterogeneity). Both San Pancho and Cocinas Islands are smaller and have fewer species than Tres Marías Islands and some islands from the Gulf of California (Grismer 2002), supporting the idea 


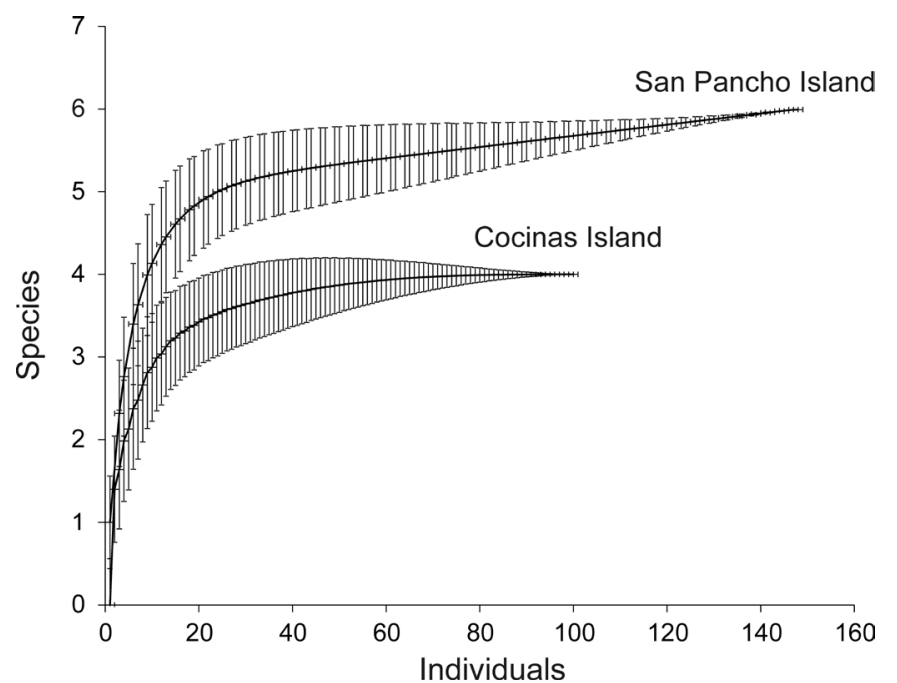

FIGURE 5. Rarefaction curves comparing the richness and the total number of individuals of different species on San Pancho and Cocinas islands, curves were plotted with 95\% confidence intervals.

that species numbers are related to island size (Boback 2003). The effects that vegetation structural complexity has on the richness and diversity of species on islands is widely recognized in studies aimed at understanding richness and diversity of species on island environments (Hortal et al. 2009) and fragmented areas on mainland (Whittaker and Fernández-Palacio 2010).

The theory of island biogeography assumes that the most distant islands from mainland should hold fewer species than nearby islands (MacArthur and Wilson 1963), and our results regarding species number supported this assumption. San Pancho Island, the smaller and closer island to mainland contained a higher species richness of reptiles than its larger counterpart. In general, distance from mainland seems to have an effect on species richness of any biological group (Whittaker and Fernández-Palacios 2010).

\section{Conservation}

Four of the seven species of reptiles found in our study (A. lineattissima, A. nebulosus, P. lanei, and U. bicarinatus) are endemic to Mexico; this underscores the need to secure the protection of these and other islands along the central Mexican Pacific (Hernández-Salinas et al. 2013). In their list from 2008, CONANP cited A. lineattissima and $A$. nebulosus from Chamela Bay; however, specific islands were not mentioned. Limited knowledge of the herpetofauna inhabiting the Chamela Bay islands is largely due to their inaccessibility. CONANP's proposal to make Chamela Bay a Natural Protected Area was based mainly on their plant diversity and on availability of critical habitat for breeding bird and bat populations (CONANP 2008). Therefore, our study represents baseline information on the herpetofauna from two of the 11 islands in Chamela Bay. Based on our results, the reptile species richness on San Pancho and particularly on Cocinas Island seem to be rather low, even though both islands are fairly close to the adjacent mainland (1.2 km and $2.2 \mathrm{~km}$, respectively), and both contain significantly fewer species than adjacent mainland areas (64 spp.; Ramírez-Bautista 1994). Nonetheless, it should be noted that the results from our study should not be regarded as the definite estimate for the total species diversity of Cocinas and San Pancho islands. Consequently,

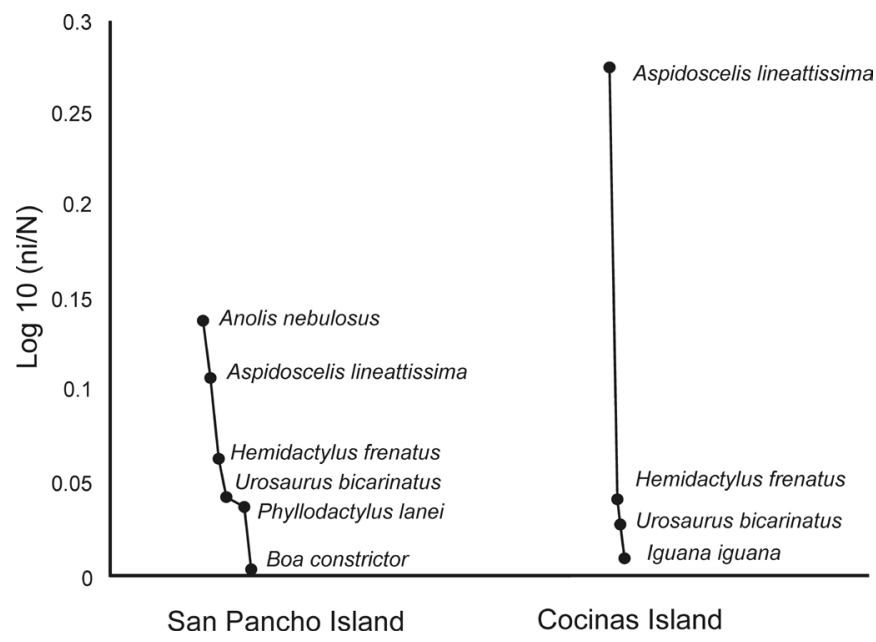

FIGURE 6. Rank-abundance curves of reptile species on San Pancho and Cocinas islands in Chamela, Jalisco, Mexico.

we propose continued sampling efforts across all seasons, along with surveying as much area as possible before a final conclusion is attained.

In addition to being important sites for reptiles, these islands also harbor important nesting sites for a large number of sea bird species; they also serve as important refuges for bats, and provide suitable habitats for a large number of arthropods (CONANP 2008). Therefore, these islands should be protected from human disturbance and access to tourism should be restricted, as well. Given their relatively small size, these islands represent very fragile environments, which make them especially susceptible to human related activities if left unregulated.

\section{ConCLUSIONS}

Although San Pancho Island is smaller than Cocinas Island, it held greater species richness, possibly due to the fact that the former is closer to mainland (Macarthur and Wilson 1967; Lomolino and Weiser 2001). Larger islands are hypothesized to have more habitats and microhabitats than smaller islands and thus, harbor more species (Macarthur and Wilson 1967; Case 2002). Thus, we concluded that distance from mainland might be playing a stronger role than island area in determining species richness. Nevertheless, although distance between the two islands from mainland seems to be only slightly different, it is interesting to note that the smaller island (San Pancho) with lower habitat diversity still contained more species.

Our results also represent new species records for Cocinas and San Pancho islands in Chamela Bay, Jalisco, Mexico. In addition, our results can be used as baseline information for more in-depth ecological studies on reptile populations on these two islands. Increased efforts to document the herpetofauna found on Cocinas and San Pancho islands, could be useful for a more thorough testing of ecological, evolutionary, and biogeographic hypotheses (Lomolino and Weiser 2001; Whittaker et al. 2008).

ACKNOWLEDGEMENTS: This paper is part of the dissertation of the graduate student UHS at the Doctorado en Ciencias en Biodiversidad y Conservación program of the Universidad Autónoma del Estado de Hidalgo. We are grateful to CONACyT for the fellowship \#233168, and projects CONABIO FB1580/JM001/12 and Fomix-CONACyT-191908. We 
thank B. Stephenson, J. D. Johnson and D. DeSantis for their comments on this manuscript. Thanks to two anonymous reviewers, who improved this manuscript. Also, we thank the authorities from the Biological Field Station "Chamela" and the Universidad Nacional Autónoma de México (UNAM) for logistic support, and SEMARNAT for research permit (\# SGPA/DGVS/04989/11).

\section{LITERATURE CiTED}

Boback, S.M. 2003. Body size evolution in snakes: Evidence from island populations. Copeia 1: 81-94. (doi: 10.1643/0045-8511(2003)003 [0081:BSEISE]2.0.C0;2).

Casas-Andreu, G., G. Valenzuela-López and A. Ramírez-Bautista. 1991. Cómo Hacer una Colección de Anfibios y Reptiles. México: Universidad Nacional Autónoma de México, Instituto de Biología. 68 pp.

Casas-Andreu, G. 1992. Anfibios y reptiles de las Islas Marías y otras islas adyacentes a la costa de Nayarit, México. Aspectos sobre su biogeografía y conservación, Universidad Nacional Autónoma de México. Anales del Instituto de Biología 63: 95-112.

Case, T.J. 2002. Reptile ecology; pp. 221-270, in: T.J. Case, M.L. Cody and E. Ezcurra (eds.) A New Island Biogeography of the Sea of Cortes. Vol. 1. New York: Oxford University Press.

CONANP (Comisión Nacional de Áreas Naturales Protegidas). 2008: Programa de Conservación y Manejo del Santuario de las Islas de la Bahía de Chamela Jalisco: México. 149 pp. (http://www.conanp.gob. $\mathrm{mx} / \mathrm{anp} / \mathrm{consulta/PMIslasBahiaChamela.pdf).}$

Feinsinger, P. 2003. El Diseño de Estudio de Campo Para la Conservación de la Biodiversidad. FAN (Fundación Amigos de la Naturaleza). Santa Cruz de la Sierra: Bolivia. 242 pp.

Flores-Villela, O. and U.O. García-Vázquez. 2014. Biodiversidad de reptiles en México. Revista Mexicana de Biodiversidad 85: 467-475 (doi: 10.7550/ rmb.43236).

Gotelli, N.J. and A. Chao. 2013. Measuring and estimating species richness, species diversity, and biotic similarity from sampling data; pp. 195-211, in: S.A. Levin (ed.). Encyclopedia of Biodiversity, Second Edition, Vol. 5. Waltham: Academic Press.

Gotelli, N.J. and R.K. Colwell. 2001. Quantifying biodiversity: Procedures and pitfalls in the measurement and comparison of species richness. Ecology Letters 4: 379-391 (doi: 10.1046/j.1461-0248.2001.00230.x).

Grismer, L.L. 1993. The insular herpetofauna of the Pacific coast of Baja California, México. Herpetological Natural History 2: 1-10.

Grismer, L.L. 2002. Amphibians and Reptiles of Baja California: Including Its Pacific islands and the Islands in the Sea of Cortés. Los Angeles: University of California Press. 399 pp.

Hernández-Salinas, U., A. Ramírez-Bautista, C. Berriozabal-Islas and D. Juárez Escamilla. 2013. First records of Urosaurus bicarinatus (Duméril, 1856) (Squamata: Phrynosomatidae) from Cocinas island, Chamela Bay, Jalisco, Mexico. Check List 9(3): 649-650 (http://www. checklist.org.br/getpdf?NGD261-12).

Hortal, J., P.A.V. Borges and C. Gaspar. 2006. Evaluating the performance of species richness estimators: sensitivity to sample grain size. Journal of Animal Ecology 75: 274-287. (doi: 10.1111/j.1365-2656.2006.01048.x).
Hortal, J., K.A. Triantis, S. Meiri, E. Thébault and S. Sfenthourakis. 2009. Island species richness increases with habitat diversity. American Naturalist 174: 205-217 (doi: 10.1086/645085).

Lomolino, M.V. and M.D. Weiser. 2001. Towards a more general speciesarea relationship: Diversity on all islands great and small. Journal of Biogeography 28: 431-445 (doi: 10.1046/j.1365-2699.2001.00550.x).

Macarthur, R.H. and E.O. Wilson. 1963. An equilibrium theory of insular zoogeography. Evolution 17: 373-387 (doi: 10.2307/2407089).

Macarthur, R.H. and E.O. Wilson. 1967. The Theory of Island Biogeography. Princeton, NJ: Princeton University Press. 203 pp.

Magurran, A.E. 1988. Ecological Diversity and Its Measurement. Princeton, NJ: Princnton University Press. 179 pp.

Magurran, A.E. 2004. Measuring Biological Diversity. Oxford: Blackwell. $256 \mathrm{pp}$.

Moreno, C.E. 2001. Métodos para medir la biodiversidad. Zaragoza: Sociedad Entomológica Aragonesa, vol. 1.86 pp.

Murphy, R.W. and B. Crabtree. 1985. Genetic relationship of the Santa Catalina Island rattleless rattlesnake, Crotalus catalinensis (Serpentes: Viperidae). Acta Zoologica Mexicana 9: 1-16.

Murphy, R.W. and F.R. Méndez De La Cruz. 2010. The herpetofauna of Baja California and its associated islands; pp. 239-273, in: L.D.Wilson, J.H. Townsend and J.D. Johnson (eds.). A Conservation Assessment and Priorities, vol. 1. Eagle Mountain, Utah: Eagle Mountain Publishing.

Ramírez-Bautista, A. 1994. Manual y Claves Ilustradas de los Anfibios y Reptiles de la Región de Chamela, Jalisco, México. Cuadernos 23. México: Universidad Nacional Autónoma de México. 127 pp.

Stejneger, L. 1899. Reptiles of the Tres Marias and Isabel islands. North American Fauna 14: 63-71. (doi: 10.3996/nafa.14.0004).

Uribe Peña, Z. and G. Gaviño De La Torre. 1978. Reptiles de las islas Tres Marías, Jalisco, México, Universidad Nacional Autónoma de México. Anales del Instituto de Biología 52: 428-438.

Whittaker, R.H. 1972. Evolution and measurement of species diversity. Taxon 21: 213-251 (doi: 10.2307/1218190).

Whittaker, R.J. and J.M. Fernández-Palacios. 2010. Island Biogeography: Ecology, Evolution and Conservation. $2^{\text {nd }}$ edition. Oxford: Oxford University Press. 401 pp.

Whittaker, R.J., K.T. Triantis and R.J. Ladle. 2008. A general dynamic theory of oceanic island biogeography. Journal of Biogeography 35: 977-994 (doi: 10.1111/j.1365-2699.2008.01892.x).

Wilson, L.D., V. Mata-Silva and J.D. Johnson. 2013. A conservation reassessment of the reptiles of Mexico based on the EVS measure. Amphibian and Reptile Conservation 7: 1-47.

Zweifel, R.G. 1960. Results of the puritan-American museum of natural history expedition to western Mexico. 9. Herpetology of the Tres Marias Islands. Bulletin of the American Museum of Natural History 119: 77-128 (http://hdl.handle.net/2246/1974).

RECEIVED: February 2014

ACCEPTED: October 2014

Published ONLINE: December 2014

EDITORIAL RESPONSIBILITY: Philippe Kok 